\title{
Antibiotic Resistance Pattern of Bacterial Pathogens in Elderly Patients Admitted in the Intensive Care Unit
}

\author{
ANDREEA LOREDANA GOLLI ${ }^{1 \#}$, FLOAREA MIMI NITU ${ }^{1}$, MARIA BALASOIU ${ }^{1}$, MARINA ALINA LUNGU², MADALINA OLTEANU ${ }^{1 \#,}$ \\ ROXANA MARIA NEME S ${ }^{3,4 *}$, MARIA FORTOFOIU ${ }^{1}$, ELENA RUSU4, MIHAI OLTEANU ${ }^{1}$ \\ ${ }^{1}$ University of Medicine and Pharmacy Craiova, 2 Petru Rares Str., 200349, Craiova, Romania \\ ${ }^{2}$ County Emergency Clinical Hospital Craiova, 1 Tabaci Str., 200642, Craiova, Romania \\ ${ }^{3}$ Marius Nasta Institute of Pneumology, 90 Viilor Road, 050152, Bucharest, Romania \\ ${ }^{4}$ Titu Maiorescu University, Faculty of Medicine, 67A Gheorghe Petrascu, 031593, Bucharest, Romania
}

\begin{abstract}
To identify and to determine the resistance pattern of bacterial pathogens involved in infections of the elderly patients ( $\geq 65$ years) admitted in the intensive care unit (ICU) at County Emergency Clinical Hospital Craiova, Romania. A retrospective study of bacterial pathogens was carried out on 463 elderly patients ( $\geq 65$ years) admitted to the ICU, from January to December 2017. The analysis of the resistance patterns for the action of the appropriate antibiotics was performed using Vitek 2 Compact system and diffusion method. In this study there were analyzed 617 samples from 463 elderly patients ( $\geq 65$ years). A total of 776 bacterial isolates were obtained, of which 175 strains of Klebsiella spp. (22.55\%), followed by MRSA - MethicillinResistant Staphylococcus Aureus (108-13.91\%) and Escherichia coli (99-12.75\%). The most common isolates were from respiratory tract (572 isolates -73.71\%). High rates of MDR were found for Pseudomonas (73.07\%), MRSA (62.03\%) and Klebsiella (44.57\%). The study revealed an alarming pattern of antibiotic resistance in the majority of ICU isolates from elderly patients ( $\geq 65$ years), which draws attention to the need for judicious use of antibiotics and for careful monitoring of the drug resistance of patients.
\end{abstract}

Keywords: elderly, antibiotic resistance, intensive care unit, bacterial pathogen

Elderly patients are more susceptible to infection and complications because the constant decline of physical function and compromised immune system, so the control of bacterial infections in hospitalized elderly patients is more important.

Hospital acquired infections (HAls) have been shown to occur about 5 to 10 times more in the patients admitted in ICUs, which are critically ill patients [1]. Infections to which the elderly patients were particularly vulnerable are respiratory tractinfections (RTIs, e.g., bronchitis, bacterial pneumonia and influenza), UTIs, intra-abdominal infections (particularly $C$. difficile), and acute bacterial skin and soft tissue infections.

A significant problem in intensive care units is constantly increasing resistance to these antibiotics, the emergence and spread of antimicrobial resistance (AMR) being now considered a global public health threat [2]

Starting from this reality, we analyzed the distribution and resistance patterns of the pathogens isolated from elderly patients hospitalized in ICU.

\section{Experimental part}

Materials and methods

The research is a retrospective study, which included the determination of pathogens involved in infections of the elderly patients ( $\geq 65$ years) admitted to the intensive care unit (ICU) of County Emergency Clinical Hospital Craiova, Romania, a county hospital with 1518 beds (65 beds of ICU), which provides specialized healthcare to patients from Dolj county and Oltenia region. Data were collected from J anuary 2017 to December 2017 from the clinical pathology databases of the hospital, including culture sensitivity reports of the elderly patients admitted to the ICU in the studied period. Samples included blood, urine, sputum/tracheal aspirate (respiratory secretion), pus/wound swabs, exudates, intravascular catheters, cerebrospinal fluid, sterile fluids. There were included in the study only those samples which were positive by culture.

The identification of the isolated strains on the clinical specimens received from ICU elderly patients was carried out in the Hospital's Laboratory of Microbiology. The analysis of the resistance patterns for the action of the appropriate antibiotics was performed using Vitek 2 Compact system and diffusion method.

Antibiotics agents employed for susceptibility testing were ampicillin-clavulanic acid $(20 / 10 \mu \mathrm{g})$, cefazolin (30 $\mu \mathrm{g})$, cefuroxime $(30 \mu \mathrm{g})$, ceftriaxone $(30 \mu \mathrm{g})$, cefotaxime (30 $\mu \mathrm{g})$ ceftazidime $(30 \mu \mathrm{g})$, cefepime $(30 \mu \mathrm{g})$, ciprofloxacin $(5 \mu \mathrm{g})$, teicoplanin $(30 \mu \mathrm{g})$, piperacillintazobactam $(30 \mu \mathrm{g})$, imipenem $(10 \mu \mathrm{g})$, meropenem (10 $\mu \mathrm{g})$, ertapenem $(10 \mu \mathrm{g})$, linezolid ( $30 \mu \mathrm{g})$, tetracycline (30 $\mu \mathrm{g})$ penicillin $(10 \mu \mathrm{g})$, erytromycin $(15 \mu \mathrm{g})$, clindamycin $(2 \mu \mathrm{g})$, clarithromycin $(15 \mu \mathrm{g})$, doxycycline $(30 \mu \mathrm{g})$ and rifampicin $(5 \mu \mathrm{g})$. Interpretation was done according to Clinical Laboratory Standard Institute (CLSI) guidelines [3].

Information about gender and age of the patients, site of infection and antimicrobial resistance pattern were collected from Hospital's Information System and from the available hospital records, the whole process relying on effective communication with patients, the family and the medical team [4], observing ethical and ethical norms specific to medical research [5].

Data were entered and analysed using Microsoft Excel. Continuous variables like age are expressed as mean \pm STDEV. The pattern of micro-organisms and gender/sites of infections were analyzed and expressed as percentages. The $\chi 2$ test was used for count data, and $p<0.05$ meant the difference was statistically significant.

\section{Results and discussions}

From January to December 2017, there were analysed 617 samples from 463 elderly patients ( $\geq 65$ years), hospitalized in ICU. The mean age of the patients was 
$75.49 \pm 6.90$ years, 212 women $(45.78 \%)$ and 251 men (54.21\%). Samples included blood, urine, sputum/tracheal aspirate (respiratory secretion), pus/wound swabs, exudates, intravascular catheters, cerebrospinal fluid, sterile fluids. There were included in the study only those samples which were positive by culture.

A total of 776 bacterial isolates were obtained, excluding cases where it was more than one isolate of the same pathogen from the same patient. Of these, 531 (68.42\%) were Gram negative and 245 isolates (31.57\%) were Gram positive bacteria. The most common isolate of the Gram negative pathogens was Klebsiella spp. (32.95\%), followed by E.coli (18.64\%) and non-fermenting Gram negative bacilli, other than Pseudomonas and Acinetobacter (NFB) (18.06\%).

The most common isolates were from respiratory tract (572 isolates $-73.71 \%$ ), followed by 91 isolates from urine $(11.73 \%, 59(7.62 \%)$ isolates from pus/wound swabs, 33 $(4.25 \%)$ isolates from blood (table 1 ).

According to our study, the most commonly isolated of all micro-organisms identified in the studied period was Klebsiella spp. (22.55\%), followed by MRSA - MethicillinResistant Staphylococcus Aureus (13.91\%), Escherichia coli (12.75\%), NFB (12.37\%), CoNS - Coagulase-negative staphylococci (11.21\%), Acinetobacter spp. (7.34\%) and Pseudomonas aeruginosa (6.70\%).

Referring to the total number of samples collected by gender, isolation rates indicates a higher value for female patients for MRSA (50.92\% compared to $49.07 \%$ ), Enterococcus spp. (63.15\% compared to $36.84 \%)$, Enterobacter spp. (70\% compared to $30 \%$ ) and Streptococcus spp. (66.66\% compared to 33.33\%) (table 2). Only one Serratia spp. strain was found in a male patient and one of Haemophilus influenzae in a female patient.

A similar percentage was highlighted for Klebsiella in other researchers' studies [6,7], but it was the second most frequent pathogen involved in infections of patients hospitalized in ICU, after Acinetobacter spp. [6,7] or Pseudomonas [7].

After other researchers, Coagulase-negative Staphylococci (CoNS) and E coli were the most frequently isolated from patient samples [9]. According to Akter atal. [10], the predominant organism isolated from ICU were $E$. coli (28\%), followed by Klebsiella spp. (27\%) and Acinetobacter spp. (17.3\%).

Similar prevalence of $S$. aureus in ICU was recorded in a study conducted in intensive care units in a university affiliated hospital in Shanghai, by Ruoming et al. (2014). [8]
The most frequently harvested samples originated from sputum/tracheal aspirate (73.71\%) and Klebsiella was the most common isolated pathogen from respiratory tract (25\%) (table 2), almost the same percentage revealed in the study conducted by Akter at al. [10].

From urine (11.73\% from all samples), E. coli was the most frequently isolated organism $(38.46 \%)$, consistent with other findings [9], while MRSA occupied, similar to the results of other researchers [11], first place among isolated pathogens from pus/wounds swabs (18.64\%), and from blood (39.39\%).

Consistent with our study, other investigators have reported also as the most common site of infection respiratory tract, urine and blood [3, 7, 12].

While antibiotics are considered the most effective method of treatment for bacterial infections, their empirical, indiscriminate, prolonged, or incorrect usage contributes significantly to the emergence of new infections by leading to the selection of resistant strains $[13,14]$.

Antimicrobial resistance (AMR) is a serious threat to public health and patient safety in Europe, leading to mounting healthcare costs, patient treatment failure, and deaths [15]. Several classes of bacteria have already exhibited multidrug resistance to antibiotics, such as Klebsiella pneumoniae and E. coli strains producing extended-spectrum beta-lactamase (ESBL), which hydrolyses the beta-lactam ring of penicillin, cephalosporins, and other related antibiotics, contributing to treatment failure [16-18].

According to the European Antimicrobial Resistance Surveillance Network (EARS-Net), the proportion of Klebsiella pneumoniae and E. coli resistant to fluoroquinolones, third generation cephalosporins, aminoglycosides and a combined resistance to the three antibiotic groups has been increased significantly between 2011-2014 [19]. This resistance is common in ESBL producing strains [20], while the emergence of resistance in Enterobacteriaceae is considered an alarming health threat [21].

We have analyzed the percentage of multidrug-resistant (MDR) strains among the clinical isolates from ICU, by taking into consideration resistance to at least three different antibiotic groups: aminoglycosides, cephalosporins, carbapenems, tetracyclines and fluoroquinolones. Almost 55\% from the Acinetobacter strains were MDR (resistant to cephalosporins, carbapenems and fluoroquinolones). High rates of MDR were found for Pseudomonas (73.07\%), MRSA (62.03\%) and Klebsiella (44.57\%), much higher than those found in

\begin{tabular}{|c|c|c|}
\hline Sample & Number of bacterial strains & $\%$ \\
\hline Exudates & 7 & 0.90 \\
\hline Intravascular catheters & 4 & 0.51 \\
\hline Sterile fluids & 7 & 0.90 \\
\hline Cerebrospinal fluid & 3 & 0.38 \\
\hline Pus/wound swabs & 59 & 7.62 \\
\hline Sputum/tracheal aspirate & 572 & 73.71 \\
\hline Urine & 91 & 11.73 \\
\hline Blood & 33 & 4.25 \\
\hline Total & 776 & 100 \\
\hline
\end{tabular}

Table 1

DISTRIBUTION OF ISOLATES AMONG SAMPLES FROM ELDERLY PATIENTS HOSPITALIZED IN ICU, COUNTY EMERGENCY CLINICAL HOSPITAL CRAIOVA, ROMANIA, BETWEEN J ANUARY-DECEMBER 2017 
Table 2

DISTRIBUTION BY GENDER OF THE MICRO-ORGANISMS ISOLATED FROM SAMPLES FROM ELDERLY PATIENTS HOSPITALIZED IN ICU, COUNTY EMERGENCY CLINICAL HOSPITAL CRAIOVA, ROMANIA, BETWEEN J ANUARY-DECEMBER 2017

\begin{tabular}{|c|c|c|c|c|c|c|}
\hline \multirow[t]{2}{*}{ Micro-organism } & \multicolumn{2}{|c|}{ Females } & \multicolumn{2}{|c|}{ Males } & \multicolumn{2}{|c|}{ Total } \\
\hline & $\mathrm{n}$ & $\%$ & $\mathrm{n}$ & $\%$ & $\mathrm{n}$ & $\%$ \\
\hline Acinetobacter & 27 & 47.36 & 30 & 52.63 & 57 & 100 \\
\hline$N F B$ & 42 & 43.75 & 54 & 56.25 & 96 & 100 \\
\hline Citrobacter & 1 & 20 & 4 & 80 & 5 & 100 \\
\hline Enterobacter & 7 & 70 & 3 & 30 & 10 & 100 \\
\hline E.coli & 49 & 49.49 & 50 & 50.50 & 99 & 100 \\
\hline Haemophilus influenzae & 1 & 100 & - & - & 1 & 100 \\
\hline Klebsiella & 79 & 45.14 & 96 & 54.85 & 175 & 100 \\
\hline Proteus & 14 & 40 & 21 & 60 & 35 & 100 \\
\hline Pseudomonas & 23 & 44.23 & 29 & 55.77 & 52 & 100 \\
\hline Serratia & - & - & 1 & 100 & 1 & 100 \\
\hline $\operatorname{CoNS}$ & 35 & 40.23 & 52 & 59.77 & 87 & 100 \\
\hline S. aureus & 10 & 50 & 10 & 50 & 20 & 100 \\
\hline$M R S A$ & 55 & 50.92 & 53 & 49.07 & 108 & 100 \\
\hline Streptococcus pneumoniae & 1 & 12.5 & 7 & 87.5 & 8 & 100 \\
\hline Enterococcus & 12 & 63.15 & 7 & 36.84 & 19 & 100 \\
\hline Streptococcus $s p$. & 2 & 66.66 & 1 & 33.33 & 3 & 100 \\
\hline Total & 358 & 100 & 418 & 100 & 776 & 100 \\
\hline
\end{tabular}

NFB- Glucose-nonfermenting Gram-negative bacilli; CoNS -- Coagulase-negative staphylococci; MRSA - Methicillin-

Resistant Staphylococcus Aureus;

other studies [12]. Less than one-third of E. coli strains were multidrug-resistant.

The antibiotic resistance rates of the isolates are summarized in tables 3-6. The combined resistance to

multiple antimicrobial groups observed for Klebsiella spp. is consistent with European Centre for Disease Prevention and control (ECDC). The majority of infections caused by

Table 3

PATTERN OF PATHOGENS ISOLATED FROM DIFFERENT SPECIMEN TYPES IN ICU

\begin{tabular}{|c|c|c|c|c|c|c|c|c|}
\hline \multirow[b]{2}{*}{ Species } & \multicolumn{8}{|c|}{ Sample } \\
\hline & $\begin{array}{c}\text { Sputum/tracheal } \\
\text { aspirate }\end{array}$ & Urine & $\begin{array}{l}\text { Pus/wound } \\
\text { swabs }\end{array}$ & Blood & $\begin{array}{l}\text { Intravascular } \\
\text { catheters }\end{array}$ & Exudate & $\begin{array}{l}\text { Sterle } \\
\text { fluids }\end{array}$ & $\begin{array}{l}\text { Cerebrosp } \\
\text { inal fluid }\end{array}$ \\
\hline Acinetobacter & 48 & & 8 & & & & & 1 \\
\hline$N F B$ & 88 & 3 & 4 & 1 & & & & \\
\hline Citrobacter & 4 & 1 & & & & & & \\
\hline Enterobacter & 1 & 9 & & & & & & \\
\hline E.coli & 51 & 35 & 9 & 2 & & & 2 & \\
\hline $\begin{array}{l}\text { Haemophilus } \\
\text { influenza }\end{array}$ & 1 & & & & & & & \\
\hline Klebsiella & 143 & 16 & 8 & 4 & & 3 & 1 & \\
\hline Proteus & 25 & 1 & 7 & & 1 & & 1 & \\
\hline Pseudomonas & 37 & 6 & 5 & & 1 & & 2 & 1 \\
\hline Serratia & 1 & & & & & & & \\
\hline CoNS & 72 & 1 & 2 & 12 & & & & \\
\hline S. aureus & 17 & & 3 & & & & & \\
\hline$M R S A$ & 77 & 1 & 11 & 13 & 1 & 4 & 1 & \\
\hline $\begin{array}{l}\text { Streptococcus } \\
\text { pneumoniae }\end{array}$ & 7 & & & & & & & 1 \\
\hline Enterococcus & & 18 & & & 1 & & & \\
\hline Streptococcus sp. & & & 2 & 1 & & & & \\
\hline Total & 572 & 91 & 59 & 33 & 4 & 7 & 7 & 4 \\
\hline
\end{tabular}


Table 4

ANTIMICROBIAL RESISTANCE PATTERN OF ENTEROBACTERIACEAE GNB (NUMBER AND PERCENTAGE)

\begin{tabular}{|c|c|c|c|c|}
\hline $\begin{array}{c}\text { Antimicrobial } \\
\text { agent }\end{array}$ & Klebsiella (175) & $\begin{array}{l}\text { E.coli } \\
(99)\end{array}$ & $\begin{array}{c}\text { Enterobacter } \\
\text { (10) }\end{array}$ & $\begin{array}{c}\text { Proteus } \\
\text { (35) }\end{array}$ \\
\hline Amoxicillin/clavulanic acid & $53(30.28 \%)$ & $38(38.38 \%)$ & $4(40 \%)$ & $10(28.57 \%)$ \\
\hline Ceftazidime & $106(60.57 \%)$ & $24(24.24 \%)$ & - & $23(65.71 \%)$ \\
\hline Ceftriaxone & $117(66.85 \%)$ & $28(28.28 \%)$ & $6(60 \%)$ & $21(60 \%)$ \\
\hline Cefotaxime & $75(42.85 \%)$ & $12(12.12 \%)$ & - & $10(28.57 \%)$ \\
\hline Cefuroxime & $106(60.57 \%)$ & $48(48.48 \%)$ & $9(90 \%)$ & $23(65.71 \%)$ \\
\hline Cefazolin & $144(82.28 \%)$ & $54(54.54 \%)$ & $8(80 \%)$ & $26(74.28 \%)$ \\
\hline Cefepime & $107(61.14 \%)$ & $23(23.23 \%)$ & $3(30 \%)$ & $20(57.14 \%)$ \\
\hline Imipenem & $44(25.14 \%)$ & $5(5.05 \%)$ & - & $11(31.42 \%)$ \\
\hline Ciprofloxacin & $80(45.71 \%)$ & $32(32.32 \%)$ & $7(70 \%)$ & $18(51.42 \%)$ \\
\hline Meropenem & $89(50.85 \%)$ & $16(16.16 \%)$ & - & $13(37.14 \%)$ \\
\hline Piperacillin/tazobactam & $116(66.28 \%)$ & - & - & $21(60 \%)$ \\
\hline Ertapenem & $74(42.28 \%)$ & $29(55.77 \%)$ & - & $10 \quad 28.57 \%)$ \\
\hline
\end{tabular}

\begin{tabular}{|l|l|l|c|}
\hline \multicolumn{1}{|c|}{$\begin{array}{c}\text { Antimicrobial } \\
\text { agent }\end{array}$} & \multicolumn{1}{|c|}{ MRSA (108) } & Enterococcus (19) & \\
\hline Ciprofloxacin & $71(65.74 \%)$ & $64(73.56 \%)$ & $14(73.68 \%)$ \\
\hline Clindamycin & $85(78.70 \%)$ & $69(79.31 \%)$ & - \\
\hline Clarytromicin & $71(65.74 \%)$ & $31(35.63 \%)$ & - \\
\hline Doxicicline & $52(59.77 \%)$ & $40(45.97 \%)$ & - \\
\hline Erytromycin & $86(79.62 \%)$ & $67(77.01 \%)$ & - \\
\hline Linesolid & $2(1.85 \%)$ & $1(1.15 \%)$ & $1(5.26 \%)$ \\
\hline Penicillin & $103(95.37 \%)$ & $85(97.70 \%)$ & $13(68.42 \%)$ \\
\hline Rifampicin & $51(47.22 \%)$ & $60(68.96 \%)$ & - \\
\hline Tetracycline & $76(70.37 \%)$ & $70(80.46 \%)$ & $12(63.15 \%)$ \\
\hline Teicoplanin & $13(12.03 \%)$ & $6(6.89 \%)$ & - \\
\hline
\end{tabular}

Table 5

ANTIMICROBIAL RESISTANCE PATTERN OF GRAM POSITIVE $\mathrm{COCI}$ (NUMBER AND PERCENTAGE)

\begin{tabular}{|l|l|l|l|}
\hline \multicolumn{1}{|c|}{$\begin{array}{c}\text { Antimicrobial } \\
\text { agent }\end{array}$} & \multicolumn{1}{|c|}{$\begin{array}{c}\text { Acinetobacter spp. (57) } \\
\text { Pseudomonas spp. } \\
(52)\end{array}$} & \multicolumn{1}{|c|}{ Other NF-GNB (96) } \\
\hline Amoxicillin/clavulanic acid & $6(10.52 \%)$ & $19(36.53 \%)$ & $41(42.70 \%)$ \\
\hline Ceftazidime & $30(66.66 \%)$ & $39(75 \%)$ & $84(37 \%)$ \\
\hline Ceftriaxone & $31(17.71 \%)$ & $34(65.38 \%)$ & $6(60 \%)$ \\
\hline Cefotaxime & $49(85.96 \%)$ & $19(36.53 \%)$ & $63(65.62)$ \\
\hline Cefuroxime & $3(5.26 \%)$ & - & $68(70.83 \%)$ \\
\hline Cefazolin & $7(12.28 \%)$ & $27(51.92 \%)$ & $87(90.62 \%)$ \\
\hline Cefepime & $43(75.43 \%)$ & $39(75 \%)$ & $79(82.29 \%)$ \\
\hline Ertapenem & $4(7.01 \%)$ & $29(55.77 \%)$ & $75(78.12 \%)$ \\
\hline Imipenem & $42(73.68 \%)$ & $19(36.53 \%)$ & $53(55.20 \%)$ \\
\hline Ciprofloxacin & $44(77.19 \%)$ & $29(55.77 \%)$ & $43(44.79 \%)$ \\
\hline Meropenem & $42(73.68 \%)$ & $31(59.61 \%)$ & $77(80.20 \%)$ \\
\hline Piperacillin/tazobactam & - & - & $83(86.45 \%)$ \\
\hline Tetracycline & - & - & $23(23.95 \%)$ \\
\hline
\end{tabular}

Table 6

ANTIMICROBIAL RESISTANCE PATTERN OF NON-FERMENTING GNB (NUMBER AND PERCENTAGE) 
K. pneu-moniae are healthcare-associated and the most common resistance phenotype was combined resistance to three key antimicrobial groups: fluoroquinolones, thirdgeneration cephalosporins and aminoglycosides [15].

$60-80 \%$ from the Klebsiella strains isolated in our study were resistant to cephalosporins, a third to amoxicillin/ clavulanic acid and $66.28 \%$ to piperacillin/tazobactam. A quarter of the Klebsiella strains were resistant imipenem and around $50 \%$ to other carbapenems, consistent to CDC analysis, which places Romania between the three countries with the highest carbapenems resistance. [15]. $K$. pneumoniae was also found to be multidrug resistant to the third generation cephalosporins and quinolone antibiotics in a research conducted by Radji et al. (2014) [22].

An increasing carbapenem resistant rate for Klebsiella, Acinetobacter and Pseudomonas was reported in their study by Akter et al (2014) [10].

Arround $40 \%$ of $E$. coli isolates were resistant to amoxicillin/clavulanic acid. Almost 95\% of the tested strains were susceptible to imipenem and $70 \%$ to ertapenem, around $75 \%$ to third and fourth-generation cephalosporins. The results are consistent with analyses from the European Centre for Disease Prevention and Control [15].

In our study, the results showed that there was statistic difference between the drug resistance rate of Klebsiella and $E$. colistrains to ceftazidime and ceftriaxone $(p<0.001)$ and to ciprofloxacin $(p<0.05)$.

A study conducted by Zheng et al. (2017) [23], on pathogenic bacteria and antibiotic resistance of Enterobacteriaceae in hospitalized elderly patients, butnot in ICU, revealed a high drug resistance rate of Escherichia coli and Klebsiella pneumoniae to sulfamethoxazole, followed by ciprofloxacin and levofloxacin.

In the Gram-positive group, a higher degree of resistance of MRSA was found to be against penicillin (95.37\%), erythromycin (79.62\%), clindamycin (78.70\%), tetracycline (70.37\%) and ciprofloxacin (65.74\%), consistent with other findings $[1,10]$. A prospective study performed in Romania by Licker at al, identified $66.51 \%$ MDR and $20.18 \%$ XDR S.aureus strains [24], in the conditions in which MRSA has been the most important cause of antimicrobial-resistant healthcare-associated infections worldwide, with higher percentages in the southern and south-eastern parts of Europe [15]. The most active antibiotic against MRSA (table 5) was linezolid, with almost all strains (105) being susceptible (table 5).

Almost all the tested strains of coagulase-negative staphylococci (CoNS) were resistant to penicillin, arround $80 \%$ to clindamycin, tetracycline and erytromycin, $70 \%$ to rifampicin (table 5).

The Enterococciisolates were resistant to ciprofloxacin (73.68\%), penicillin $(68.42 \%)$, and tetracycline $(63.15 \%)$, and almost all strains were susceptible to linezolid.

All the tested strains of Pseudomonas aeruginosa (36.53\% from all strains) were resistant to amoxicillin/ clavulanic acid, $75 \%$ to ceftazidime and cefepime. $36.53 \%$ from the strains were resistant to imipenem and between $55-605 \%$ to ciprofloxacin, meropenem and ertapenem (table 6). The resistance to ceftazidime and cefepime observed in our study was similar to that of a previous report on multidrug-resistant Pseudomonas aeruginosa, which also revealed that $80 \%$ of $P$. aeruginosa were resistant to carbapenem antibiotics such as imipenem and meropenem $[25,26] .26 .27 \%$ of the Pseudomonas strains have been found to be resistant to carboxypenicillins and ureidopenicillins in a study conducted by Axente et al. [27].
A very high level of resistance was found for the tested strains of other non fermenting Gram negative bacilli (other NF-GNB) (between 90-99\%), to amoxicillin/clavulanic acid, to all generations of cephalosporins, ciprofloxacin, piperacillin/tazobactam, imipenem, tetracycline $[28,29]$. Only one strain was found resistant to linezolid (table 6).

A high resistance to the carbapenems (73\%) was found for the Acinetobacter strains, which were also resistant to cefotaxime $(86 \%)$, cefepime $(75.43 \%)$, ciprofloxacin (77.19\%) and ceftazidime (66.66\%). In another research conducted in Saudi Arabia on multidrug resistance Acinetobacter species at the intensive care unit, it was found a much higher percentage -over $90 \%$ - of resistant strains to the same antibiotics [30].

In our study, for all the other NF-GNB strains, a high degree of resistance has been observed on cephalosporins, carbapenems and ureido-penicillins, consistent with other findings [1].Moolchandani $K$. et al have reported concordance resistance pattern to various classes of antimicrobials for Acinetobacter and Pseudomonas [1]

Another study conducted in Romania by Axente et al. evidenced an increased resistance $(69.95 \%$ resistant strains) to penicillins ( presently less frequently prescribed in ICUs) found in GNB [27].

This study only refers to infections in elderly patients (over 65 years of age) admitted to ICU, because there are very few studies reported only for this vulnerable age group, with particularities of response to antibiotic therapy (especially if is correlated with other substances intake) [31] . Comparisons of the prevalence of isolated germs and their antibiotic resistance were made with the results obtained in studies that took into account all age groups, considering the fact that the elderly represent the majority of the cases admitted to the ICU.

\section{Conclusions}

The study revealed an alarming pattern of antibiotic resistance in the majority of ICU isolates from elderly patients ( $\geq 65$ years). The detection of bacterial resistance is an important way to observe the clinical rational use of drugs, in which the laboratory plays a very important role.

Surveillance of antibiotic prescription and monitoring studies are required to reduce the risk of resistance, together with direct communication between clinicians and microbiologists for adopting individual therapeutic measures and using appropriate antibiotics based on antibiogram. It is also necessary to collaborate with the epidemiologist in order to apply the measures for the control hospital acquired infections.

\section{References}

1.MOOLCHANDANI, K.., SASTRY, AS., DEEPASHREE, R., SISTLA, S., HARISH, BN., MANDAL, J., J. Clin. Diagn. Research., 11, nr. 2, 2017, p. DC01-DC07

2.NÚNEZ, M., NAVARRO, M.D., PALOMO, V., RAJ ENDRAN, N.B., DEL TORO, M.D., VOSS, A., SHARLAND, M., SIFAKIS, F., TACCONELLI, E., RODRIGUEZ-BANO, J., Clin. Microbiol. Infect., 24, nr. 2, 2018, p.105109

3.PATEL, JB., WEINSTEIN, MP., ELIOPOULOS, GM., JENKINS, SG., LEWIS, J S., LIMBAGO, B., MATHERS, AJ ., MAZZULLI, T., PATEL, R., RICHTER, SS., SATLIN, M., SWENSON, JM., TRACZEWSKI, MM., TURNIDGE, JD., ZIMMER, BL. CLSI. Performance Standards for Antimicrobial Susceptibility Testing; 27th Edition, Clinical and Laboratory Standards Institute.

4.CONSTANTIN, DA., CIORICEANU, IH., TANTU, MM., POPA, D., BADAU, D., BURTEA, V., NEMET, GC., ROGOZEA, LM., Rom. J. Morphol. Embryol., 58, nr. 3, 2017, p.1121-1125

5.ROGOZEA, L., PURCARU, D., LEASU, F., NEMET, C., Rom. J. Morphol. Embryol., 55, nr. 2 suppl, 2014, p.719-722 
6.SAAED, NK., KAMBAL, AM., EL-KHIZZI, NA. Saudi Med. J., 31, nr. 2, 2010, p.1341-9

7.NEUHAUSER, MM., WEINSTEIN, RA., RYDMAN, R., DANZIGER, LH., KARAM, G., QUINN, JP., JAMA, 289, nr. 7, 2003, p.885-8

8.RUOMING, T., JIALIN, L., MEILING, L., JIE, H., JINGYONG, S., HONGPING, Q., J. Microbiol. Immunol. Infect., 47, nr. 2, 2014, p.87-94. 9.J APONI, A., VAZIN, A., HAMAD, M., DAVARPANAH, MA., ALBORZI, A., RAFAATPOUR, N., Braz. J. Infect. Dis., 13, nr. 1, 2009, p.82-86

10.AKTER, T., MURSHED, M., BEGUM, T., NAHAR, K., DUZA, SS., SHAHNAZ, S., Bangladesh J. Med. Microbiol., 08, nr. 01, 2014, p.07-11 11.KHAN, RA., KHAN, FA., IQBAL, M., NIGAR, H., Anaesthesia, Pain \& Intensive Care, 18, nr. 3, 2014, p.231-236

12.HAMISHEHKAR, H., SHADMEHR, P., MAHMOODPOOR, A., MASHAYEKHI, SO., ENTEZARI-MALEKI, T., Braz. J. Pharm. Sci., 52, nr. 3, 2016, p.403-412

13.LAXMINARAYAN, R., DUSE, A., WATTAL, C., ZAIDI, AK., WERTHEIM, HF., SUMPRADIT, N., VLIEGHE, E., HARA, GL., GOULD, IM., GOOSSENS, H. et al., Lancet Infect. Dis., 13, nr.12, 2013, p.1057-1098.

14.LLOR, C., BJ ERRUM, L., Ther. Adv. Drug Saf., 5, nr. 6, 2014, p.229241

15.*** Antimicrobial resistance surveillance in Europe, SURVEILLANCE REPORT, 2015, www.ecdc.europa.eu.

16.CHERKAOUI, A., EMONE,T S., RENZI, G., RIAT, A., GREUB, G., SCHRENZEL, J., Rev. Med. Suisse., 10, 2014, p.2142-2148.

17.TRANG, NHT., NGA, TVT., CAMPBELL, JI., HIEP, NT., FARRAR, J ., BAKER, S., DUY, PT., J. Infect.Dev. Ctries., 7, 2013, p. 922-928.

18.RUSU, E., SARBU, I., CRISTESCU, C., COCULESCU, BI., MOLDOVAN, H., PETRUT, S., MURESAN, A., ET.AL., Rev. Chim. (Bucharest), 67, nr. 12,2016, p.2417

19.ZILAHI, G., ARTIGAS, A., MARTIN LOECHES, I., Ann. Intens. Care, 6, nr. 1, 2016, p.96
20.FRAIMOW, HS., TSIGRELIS, C.,. Crit. Care Clin., 27, nr. 1, 2011, p.163-205.

21.RUSSOTTO, V., CORTEGIANI, A., GRAZIANO, G., SAPORITO L., RAINERI, SM., MAMMINA, C., GIARRATANO, A., Infect. Drug Resist., 8, 2015, p.287-296.

22.RADJI, M., FAUZIAH, S., ARIBINUK, N., Asian Pac. J. Trop. Biomed., $1, \mathrm{nr} .1,2011$, p.39-42

23.ZHENG, F., MENG, X., Biomed. Res., 28, nr. 16, 2017, p. 7243-7247. 24.LICKER, M., ANGHEL, A., MOLDOVAN, R., HOGEA, E., MUNTEAN, D., HORHAT, F., SECLAMAN, E., TAMAS, L., ANGHEL, M., BADITOIU, L, Rev. Chim (Bucharest), 68, no. 11, 2017, p.2546-2550

25.GILL, JS., ARORA, S., KHANNA, SP., HARI KUMAR, KVS. J. Global Infect. Dis., 8, nr. 4, 2016, p.155-159

26.CURUTIU, C., CHIFIRIUC, CM., MITACHE, MM., Curr. Org. Chem., 17, nr. 6, 2013, p.149-154

27.AXENTE, C., MUNTEAN, D., BADITOIU, L., MOLDOVAN, R., HOGEA, E., HORHAT, F., BEDREAG, O., SANDESC, D., DUGAESESCU, D., VOICU, M., DUMITRASCU, V., LICKER, M., Rev. Chim. (Bucharest), 68, no. 6, 2017, p.1223-1226.

28.MITACHE, M.M., GHEORGHE, I., TOTEA, G., BLEOTU C., CURUTIU, C., COCHIOR, D., RUSU, E., CHIFIRIUC, CM., Rev. Chim. (Bucharest), 68, no. 5, 2017, p.997-1001

29.MITACHE, M.M., CURUTIU, C., RUSU, E., BAHNA, R., DITU, M., MOLDOVAN, H., HANCU, V., CHIFIRIUC, CM., Rev. Chim. (Bucharest), 68, no. 3, 2017, p.566-569

30.AL BSHABSHE, A., JOSEPH, MRP., AL HUSSEIN, A., HAIMOUR, W., HAMID, ME., Asian Pac. J. Trop. Med., 9, nr. 9, 2016, p.903-908.

31.POP, CS., POMOHACl, C., IUCU, R., STINGU, M., NEMES, R.M. Rev. Cercetare Interv. Soc., 51, 2015, p.41-55

$\overline{\text { Manuscript received: } 31.08 .2018}$ 